\title{
Good Leadership: A Catalyst for Nigeria's Quest for Development
}

\author{
Adefarasin VO* \\ Department of Philosophy, Olabisi Onabanjo University, Nigeria
}

*Corresponding author: Dr. Adefarasin VO, Department of Philosophy, Olabisi Onabanjo University, Ago-Iwoye, Nigeria, Tel: 08033907552; Email: adefarasinvo@yahoo.com

\section{Research article \\ Volume 3 Issue 3}

Received Date: August 06, 2020

Published Date: September 17, 2020

DOI: $10.23880 /$ phij-16000149

\section{Abstract}

The paper defends the thesis that good leadership is a sine qua non for Nigeria's development. Nigeria, without doubt, is rich and blessed with human and natural resources, yet, she is poor. She is poor as a result of lack of good leadership which is a hallmark of sustainable development. It is rather pathetic and indeed unfortunate that after sixty years (60 years) of her independence, Nigeria is still a sleeping giant of Africa. The reason for this backwardness is as a result of lack of good, transparent and visionary leadership which can steer the ship of Nation to greater heights. It is against this background that the paper discusses what is meant by leadership, types of leadership, qualities of a good leader, development, dimensions of development and features of development. It also discusses the nexus or synergy that exists between leadership and development. The paper concludes that the development of Nigeria is and will continue to be very much dependent on good leadership.

Keyword: Leadership; Catalyst; Nigeria and development

\section{Introduction}

There is no gainsaying the fact that Nigeria has been experiencing the crisis of leadership since independence. This has inadvertently stunted her growth and development. Little wonder Nigeria suffers from many crisis. Leadership plays a pivotal role in changing the cause of a nation and mapping out its destiny because it involves the provision of direction and foresight in the making of decisions that could influence people's lives either positively. Tella [1] subscribes tenaciously to this by saying that "the problem of underdevelopment of Nigeria has to do with the quality of leadership on the continent. But it is this leadership that must provide the environment conducive for development". Again, George [2] declares that Lack of effective leadership is the main bane of the diabetes in our national economy, it is analogous to insulin in the body of the diabetic patient. Qualitative leadership with defined vision and mission is a 'sine qua non' for good governance and good management of the economy. The choice of a good leader determines the degree of good governance. In the Nigerian context, this has been a major bane, with experimentations with different democratic processes after the traumatic experiences of military rule.

In addition, Achebe [3] asks the following questions:

"How does Nigeria bring all the human and material resources it has to bear on its development? How do we clean up the Niger Delta? What do we need to do to bring an end to organized ethnic bigotry? How can we place the necessary checks and balances in place that will reduce the decadence, corruption and debauchery of the past several decades? How can we ensure even and sustained development?"

Nigeria has never been lucky in terms of good leadership. Thus, in the wake of current global realities this paper is not, only relevant, but timely. The consequences of bad leadership are enormous. For instance, the global financial recession or meltdown which tears the foundations of previously acclaimed World strongest economics into pieces is a malady that would be difficult to remedy because of the 


\section{Philosophy International Journal}

failure of leadership. Achebe discusses in some detail the issue of leadership in some of his novels particularly, a man of the people and the Anthills of the Savannah.

This, without doubt shows that no nation can survive without good leadership. Achebe [4] maintains that: The trouble with Nigeria is simply and squarely a failure of leadership. The Nigerian problem is the unwillingness or inability of its leaders to rise to the responsibility to the challenge of personal example which are the hallmark of true leadership.

In consonance with Achebe's position, Ayyiteh [5] adds to that discourse by affirming that despite the rhetoric and vituperations against colonialism, very little changed in the years immediately following independence. For many countries, independence meant only a change in the colour of the administrators from white to black. The new leaders began to act in the same manner as the colonialists. In fact, in many places, they were worse than colonialists. It is therefore an irony of fate that many African leaders (Nigerian leaders inclusive) came to assume some of the very same characteristics they so loudly denounced. The questions that agitate our minds are: Are our leaders really well trained? Do they actually and adequately prepare for leadership positions? Falaiye [6] avers that: No one accepts an untrained doctor or lawyer, but all would seem to accept untrained leaders/politicians. People put themselves up for leadership positions without training, formal or informal. They simply wake up and contest for high offices; their qualifications, money, ethnic affiliation and/ religious affiliation and sometimes, the gift of the garb.

According to Ihonvbere [7] leadership is the key to peace, development and progress. Any country or organization without purposeful leadership cannot make progress, no matter its resource endowments. The history of Africa is littered with very sad tales of bad, insensitive, arrogant, and ineffective leaders that have failed to inspire the people. A year of bad leadership can spell disaster for any nation or organization. The African condition today has been directly complicated by bad leaders; those that Fela calls VIPs Vagabonds in Power. It is common knowledge that most African leaders do not read and are technologically challenged. They waste so much time talking, meeting, and inventing or pursuing enemies that they have little or no time to build real leadership qualities. They do not prepare successors and any other rising star is an enemy that must be framed, harassed, crippled financially, and eliminated or chased far away. They build false popularity profiles by paying for and receiving useless honorary degrees, chieftaincy titles and awards from useless organizations. They lack the qualities of compassion, vision, education, capacity, capability, dignity, exposure, hard work, consultation, ability to listen, and a clear and real track record of service to the people. They put up billboards, name buildings and roads after themselves, set up youth vanguards, turn the local television and radio into their personal newsletters and appoint opportunists and praise singers into positions to recycle the same culture of mediocrity and eye service. Such leaders cannot build relative autonomy, hegemony, establish lasting institutions, and live in the hearts of the people forever. Cheap popularity, not anchored on service, honesty, integrity and performance is a waste of money and time. Our leaders spend public funds as if it is generated from their hard labour or that the money comes from some family savings. We must build new visions, new voices, new hopes, new constituencies and new leaderships at all levels. Our schools lack courses on leadership. Government does not support youth organizations or NGOs that build new leaders. Because we are greedy for power, we do not believe in building a successor generation. The few leadership institute that dot the continent are often not well funded. Once you loot the treasury, build a big house and buy a big expensive car, you are automatically a "leader." Unless we begin to look seriously into these issues, supporting youth groups, taking social studies, history and civics seriously, encouraging creativity, courage and innovation, and rewarding hard work and achievement, we will make no progress. We must go beyond posturing, noise, long speeches to seriously articulating a holistic strategy for leadership development. Bad leaders, if not stopped, will destroy Africa!

\section{Research Problem}

The problem that inspires this paper is the crisis of leadership and development in Nigeria. The evident paradox crises of leadership and development in Nigeria are that despite the vast volumes of research done, the issue itself seems impervious to any viable solution.

\section{Objective of this paper}

This paper seeks to achieve the following objectives:

1. The good leadership is a necessary condition for development.

2. To examine the nexus or synergy that exists between leadership and development.

3. That the development of Nigeria is much dependent on good leadership.

\section{Theoretical Framework}

Theoretical framework connotes theoretical principles upon which a research work is based. In philosophical studies, it is referred to as the philosophical foundation or principle which the paper proceeds from. The theoretical underpinning this paper is self-reliancism. By this, we mean the principle of self-reliance. Self-reliancism is the 


\section{Philosophy International Journal}

realization of the principle of self-reliance. It is the ideology or orientation based on this principle. It symbolizes selfdetermination, which is anchored on the will to be free. This is important because Nigeria needs good leaders in order for her to develop and join comity of Nations.

\section{Results of the study of this paper}

Results showed that:

$>$ Nigeria is rich, both in human and natural resources.

$>$ Bad leadership is the bane of Nigeria's problem.

$>$ Good leadership is the hallmark of development.

$>$ Leadership plays a vital role in Nigeria's quest for development.

\section{Discussion}

A cursory look at the paper reveals that the reason for Nigeria's backwardness is the lack of good, transparent and visionary leadership which can steer the ship of the nation to greater heights. Nigeria remains a sleeping giant despite her huge potentials, as a result of bad leadership.

\section{Leadership Defined}

"Leadership is the capacity to translate vision into reality"

- Warren Bennies

"Leaders aren't born; they are made through hard Work". Vince Lombardi

"The task of the leader is to get his people from where they are to where they have not been". - Henry Kissinger

Leadership derives from the verb "to lead". To lead means to "guide or cause the follow one or to direct, as by persuasion or influence, to a course of, to conduct in a certain direction or to be the head [8]. A leader is someone who leads, plans, organizes, controls, delegates, accepts the responsibility, to reach the societal goals. To be a leader is to be ready to serve, initiate and create.

The Kernel of our argument is that where there is an enlightened and high quality type of leadership, there is bound to be a high level of performance, rapid socio-economic development and a high standard of living in the country. On the other hand, where the leadership is incompetent, unenlightened and indecisive, the rate of development will be slow. Timamy [9] says "As regards good leadership, great lessons from history are not hard to come by. In the United States, the first Head of State of independent America, George Washington, who was part of the old guard and centrally involved in the anti-colonial struggle against the British government, stepped down voluntarily after just one term in office to pave way for more energetic Americans. He did not lecture the new generation of Americans on their lack of requisite political and managerial skills in handling affairs of government. In South Africa, Nelson Mandela broadmindedly relinquished power as head of an independent democratic government to clear the way for the injection of younger blood. Only power-crazy individuals would plan to go on, and on, as Margaret Thatcher had ironically put it".

Having explained what leadership means, we shall now discuss the qualities of a good leader.

\section{Qualities of a Good Leader}

A nation is as good as her leaders. It is therefore expedient that leaders should possess certain qualities that will positively transform the nation to unprecedented development.

Without mincing words, a leader by all known standard must possess the skill to be able to create, catch and develop visions. By vision, we mean the ability to transform mental pictures into a desired future. Also, a leader must be willing to take responsibility for his actions and for others that are working with him; he must equally realize that a lot of people are looking up to him for direction, motivation and inspiration. What this boils down to is that he cannot afford to fail them.

Again, a leader should possess mental toughness. Before someone can aspire for leadership position, such a person must be knowledgeable because knowledge is the way to understanding and understanding is the way to power.

Moreover, Ojukwu [10] declares that:

One essential demand of leadership is to be like a waste basket, a dustbin where all dirts and rubbish are heaped. Whoever is not ready to accept such treatment does not qualify to be a leader. He goes on to say that every leader must have a dream and be steadfast in his efforts to fulfill that dream. In the same vein, a leader does not complain when things are not going too well since, that is one of the occupational hazards. A leader must not try to cushion himself (by amassing wealth) against the future. Though, the temptation is great, there is nothing more counterproductive in leadership than corruption. A leader has to be above board in all his dealings.

In consonance with the view of Ojukwu, Momoh $[10,11]$ avers that:

Any leader who doesn't keep the brightest and the best is not fit to be a leader. You have to keep your best and highest or you will not progress. The key to any leadership is nurturing talent and increasing that pool which then increases the quality of government and business. 


\section{Philosophy International Journal}

Our clarion call is that Nigeria needs transformational leaders who can set up lofty goals of reforming the Nigerian society and fight to achieve them no matter the frustrations or setbacks. As it is now, Nigeria needs God fearing, visionary, selfless, sacrificial, reformatory, proactive, efficient and effective leaders.

At this juncture, the words of Julius Nyerere as being quoted by Hagher [12] are refreshing here: We say man is created in the image of God, I refuse to imagine a God who is poor, ignorant, superstitious, fearful, oppressed, wretched - which is the lot of the majority of those he created in His image. Men are creators of themselves and their conditions; under present conditions, we are creatures, not of God, but of our fellow men.

\section{Definitions of Development}

The World currently revolves around development. This is because the need for development occupies a primary place in the lives of individuals, groups, nations and states. The desire is always for a people to move closer to development. Those who are farthest from it wish they were closer and consistently strive to be closer to it, while those who are close to it wish there were nothing separating them from development.

The problem of development is a nagging and recurrent issue. Like an ailment, it has received several diagnoses, prognoses and treatment. Yet, the disease persists. It does not seem that it can be totally cured. Some countries seem to have achieved self-sustaining growth. Some are striving for it, while others are not only finding it difficult to attain, but also seem to be stagnant, especially, economically. Usually, developed countries, particularly, advanced capitalist ones, initiate and execute ethnocentric policies with little or no regard for the interests of underdeveloped one.

The vagueness of the term notwithstanding, most people assume that they have a clear idea or, in the very least, an insight into the nature of development. Their means of arriving at this assumption is identified by Starr John (1973:30) who observes that:

A series of stages is postulated through which the underdevelopment system must pass through in order to reach the condition of being politically developed. These series of stages, based on the Western experience, then comes to be revealed as being an absolute rather than an arbitrary scale for measuring political and social development and in the process, the values that govern the definition of the condition of being developed are never made explicit.

Although, Starr's comments refer, primarily to political development, it could be generalized to cover all aspects of development. Starr's comments become even more valid when we recognize the fact that most assumptions concerning the concept are based on a naïve identification of development with modernization. But as Wiredu observes, "modernization is the application of results of modern science for the improvement of the conditions of human life. It is only the more visible side of development ... Because, modernization is not the whole of development, there is need to view it in a wider human perspective" [13].

In the same vein, it needs be stated that every country, nation, is of course developing, for no nation in the World has yet reached the highest point of development, nor is that even possible. No country in the World has ceased to develop or has no further need for improvement. Every country is therefore a developing country for there will always be need for improvement and to cease to develop amounts to retrogression. This is, of course, not deny or ignore the plain fact that some countries are more developed than others. But this is a matter of degree within the same process, for all countries are going through the same process of development though some have attained higher degrees of it than others.

According to Henry McGurk [14] "development implies not only a change in time but also change which has direction; development frequently implies advancement or improvement over some more primitive status". Harris Dale defines development as "a sequence of continuous changes eventuating in some outcome" [15]. What this adds to the McGurk's position is that developmental change is not isolated incident. It must be part of a process emanating from the past and gradually building up to the present and the future. Harris also adds that it has as its essential components "the notions of a system possessing a definite structure and a definite set of pre-existing capacities; and the notion of a system yielding permanent but novel increment not only in structure, but in its modes of operation as well" (Ibid, 17). This is to say that developmental changes cannot be accidental, but, must emanate from perceptible capacities, which exist in a well-structured medium. Also, such changes result in a state that is not only different, but also qualitatively more desirable than the former state. Thus, development is not something that can be thrust upon a state or a system; it must be something that emanates from within. A question can be asked whether a change has to be purposive and intentional in order to be developmental. This query emanates from Sidney Hook's characterization of development. Hook refers to development as any change which has a continuous direction and which culminates in a phase that is qualitatively new. Hence, the term should be used to characterize any series of events in thought, action or institutional arrangement which exhibits a directional cumulative change that either terminates in an event marked off by a recognized qualitative novelty or which exhibits in 


\section{Philosophy International Journal}

its course, a perceptible pattern of growth. The suggestion by Hook that the term, development be applied only to events in thought, action and institutional arrangement seems to suggest that every developmental change is purposive, and intentional. But is this really the case? Is Hook correct in limiting the application of the term to the human sphere? The problem raised here goes beyond the scope of the present enterprise because; it raises the general question of applying human concepts to non-human events. This notwithstanding, it appears that making a distinction between a general concept of development and a concept of development within the human sphere amounts to creating a straw man. This is because, the general concept of development, just like any restricted concept of the term, is a human concept.

In his own conceptualization of development, Baster Nancy says that 'the questions to ask about a country's development are: What has been happening to poverty, unemployment, inequality? If all these three have become less severe, then beyond doubt, this has been a period of development for the country's concerned". For Frances Stewart (1977:19-22) technology is the backbone of development, without it, no country can be said to have developed.

Again, in the existential ontology of Martin Heidegger, development can be understood as the achievement of authentic nationhood; and underdevelopment, the inability of a nation to overcome confidence-crisis. Any nation that thus refuses or is incapable of building on its factical givens cannot be a sovereign nation, where a sovereign nation is understood to be a nation that is free from external determination and control [16].

Ake [17] argues that development can only be related to and driven by social will in the context of democracy. It is only in this context that the people can be a means and the end of development." Put differently, development is best initiated internally and nurtured by the people in need of a particular development, otherwise, there can never be development. Development can also be described as "the mind leading to a complete mastery over nature in which can be the humanity of man is no longer subjugated to nature" [18]. Udoidem Iniobong [19] maintains that development can be defined as "a process leading to the realization of full human and environmental potentials. If, therefore, in our thrust toward community development, the full human and environmental potentials are not realized, then, the community is yet to be developed". Also, Ogundowole [20] opines that "meaningful development is self-realization". This implies the use of the resources of geosphere, imagination and unprecedented ingenuity to achieve overall societal objectives. It entails the increasing expansion of what a purposeful self-realiancist mind, poised at full realization and recovery can do with simple objects of his immediate geographical and historical environment. Hence, it may be said that development is not so much a matter of what we have, but, of what we do with what we have; how we do it and how well". He goes further to say that development, thus, is the desire and ability to use what is available to continuously improve the quality of life, liberate people from the hazardous power and influence of natural geophysical, socio-historical and World environment. In a nutshell, development must begin with the desire to improve lot through our own efforts. According to Ogundowole, development then, is like ambition, it cannot be received by people from another people. Development requires the ability to learn how to improve one's own wellbeing. It involves the ability to act and while acting to apply knowledge thoroughly in all spheres of activity. He goes further by stressing that development as a process, and as a concept, is broader and is multi-dimensional. It may mean a mechanical motion, the spatial displacement of objects. It may mean a forward, backward, sideways, upward and/ or downward movement. It may mean rectilinear, rotatory, oscillating, etc motion" (Ibid, 164). He goes on to say that for Frantz Fannon and Nkrumah, both hold that development means decolonization, and Nyerere who insists that development is liberation.

According to Miller [21] "a development is a temporal change having a beginning and end. It is unit of progress, a real unit of change. Secondly, it is a recognizable and describable process, one that recurs again and again at different times and places. And thirdly, it is a cumulative or directed process, one which points throughout its course to certain definable goal or terminus". On his part, Pearson [22] maintains that development is partly a process whereby a country achieves a reasonable self-sustaining growth which facilitates and enhances industrial and technological progress in the interest of its people". Some of the pre requisites for this type of development according to him are: the application of modern science and technology, reasonable political stability, and efficient administration and organization. He affirms that development takes place when the people participate in the determination of their environment, and are allowed to choose and use their resources to the maximum capacity.

Development is also seen as a growth from a certain stage of life conceived to be primitive to another stage conceived to be modern. Development involves "a series of interactions (social relations) and other factors which in Africa would include values, way of life, beliefs, traditions as well as good governance, which allows human participation at all levels of decision making" [23]. Now, of all these plethora of definitions of development, the study adopts the definitions which says that development is the act of developing into a 


\section{Philosophy International Journal}

form of something. In other words, to develop is to expand or realize the potentials of bringing gradually into a fuller, greater, or better state. One of the reasons for this is that development should not be a stagnant thing; it should go with changes; it should equally go with new dimensions, innovations, advancement and new ideas. It should move from one stage into another that will lead to new discoveries.

\section{Dimensions of Development}

Development is a many-sided process. It is not a unitary or homogeneous concept; it is multidimensional, for, it appears in all aspects of human endeavour. The term development stands out as primary icon in various aspects of human theatre. This idea of development as being multidimensional is further reinforced in that "development has economic, social, political, cultural, educational, technological, human and personal dimensions" [24]. In addition to these dimensions, we shall include and discuss moral and religious dimensions of development.

\section{Human Development}

If any development drive is to be meaningful, it must be people oriented. Development efforts that are not targeted at the well-being of the people cannot be said to be meaningful. The primary aspect of development in any country is the development of human dimension. In other words, development of human personality is primarily the development of a nation. All other aspects of development are subordinate and instrumental to human development.

\section{Economic Development}

Economic development is characterized with improvement in quality of life coupled with the liberation from the yoke of unproductivity and retrogressiveness as well as static economic situation. A country is said to be economically developed, when the country is independently of outside control or direction, organizes the exploitation and development of its total resources, for the benefits of its entire people under a system in which the forces of supply and demand and marginal utility are controlled for the common good [25]. What this boils down to is that the extent to which a country maximizes the available resources determines the strength of her economy.

\section{Educational Development}

Educational development occupies another aspect of development worthy of discussion. And for there to be human development, the educational prerequisite for development must be fulfilled. The more a state is developed educationally, the more it is susceptible to an all-enhancing development.

\section{Political Development}

To speak of political development, is to emphasize on "the qualitative increase in the level of the involvement of the people in the appointment of those with whom they trust their political destinies" [26]. A politically developed state implies an enhanced political participation based on the principle of accountability. That is, those who govern the state are accountable to those they govern. Political development in a state is determined by the degree and level of the democratization process in the state.

\section{Social Development}

Related to political development is social development. Though, many people have erroneously conceived social development to mean the provision of social services or the promotion of social welfare or independence from development aids. It involves the promotion of social reform human dignity and justice. Social development involves the respect for the views of others, acceptance of plurality of opinions as well as respect for the views of others.

\section{Technological Development}

Technological development is the qualitative advancement recorded in the civilization of science and the technical application of its results. Technological development is the consistent increase in the application of the result of science for the improvement of the conditions of human life and control of man's environment for the suitability and comfort of man.

\section{Cultural Development}

Cultural development is the expanding and adaptive capacity of the society in satisfying the material and cultural needs of its members" [13].

\section{Religious Development}

No development programme is completed without including within it a programme for religious upliftment and development. Religious development is the qualitative and quantitative increase in the purification of man's soul and accentuation towards the will of the supreme beingGod. Religious development affords the citizens to foresee, identify, condemn and abstain from evil always wherever and whenever it surfaces in the society.

\section{Moral Development}

Morality is indispensable to development. The recent call for moral regeneration by scholars admits the quest for development, reinforces the importance of moral 


\section{Philosophy International Journal}

development. In fact, it can rightly be said that moral development is the basis for a well-rounded development. In other words, the prosperity of a society depends on the moral disposition of its members. Put differently, a state or society can never experience true development when the citizens are morally deficient. This position is akin to Omoregbe's conception of development when he opines that: moral development on the part of the citizens is therefore a condition sine qua non for the development of any nation.

\section{Features of Development}

These are some of the features of development:

$>$ Promotion of equality of the people. This means that everybody is equal to enjoy the resources of the land, no difference between the rich and the poor.

$>$ Absence of exploitation. There should not be any form of exploitation from the rulers to the ruled.

$>$ Promotion of the dignity and respect for human beings. Human dignity and values must be respected at all times. People should not be treated like slaves or second class citizens.

$>$ Avoidance of discrimination on grounds of sex or colour. There should neither be discrimination nor segregation on the grounds of sex or colour. In other words, being feminine or masculine should not be a basis, yardstick, parameter or a criterion in the distribution of resources.

$>$ Promotion of national independence at self-reliance. Self-reliacism is the realization of the principle of selfreliance. It is the ideology or orientation based on this principle; a set of purposeful activities directed towards self-realisation.

\section{Rodney's Conception of Features of Development}

Walter Rodney is of the view that developed economies have many features which contrast with underdeveloped ones. For the purpose of clarity and elucidation therefore, these features will now be fully itemized and explained. According to him, developed countries are all industrialized. That is to say, the greater part of their working population is engaged in industry rather than agriculture, and most of their wealth comes out of mines, factories etc. [27]. They have a high output of labour per man in industry because of their advanced technology and skills. This is well known but it is also striking that the developed countries, have a much more advanced agriculture than the rest of the World. Their Agriculture has already become an industry, and the agricultural part of the economy produces more although it is small. He stresses further that the countries because they rely on agriculture and have little or no industry; but their agriculture is unscientific and the yields are far less than those of the developed countries.
Another feature of development according to him is that the social services provided by a country are of importance equal to that of its material production in bringing about well- being and happiness. It is universally accepted that the state has the responsibility to establish schools and hospitals but whether these are provided by the government or by private agencies, their numbers can be established in relation to the size of the population. The extent to which basic goods and social services are available in a country can also be measured indirectly by looking at the life expectancy, the frequency of deaths among children, the amount of malnutrition, the occurrence of diseases which could be prevented by inoculation and public health services, and the proportion of illiterates. In all these respects, the comparison between the developed and underdeveloped countries shows huge and even frightening differences (Ibid, 25).

Again, Rodney opines that it takes a large number of skilled people to make an industrial economy function; while the countries of Africa have a woefully insufficient number of highly qualified personnel. In African countries, professionals, technicians, high level of administrators and skilled workers emigrate from their homes and the small number of skilled people available to the underdeveloped World is further depleted by the lure of better pay and opportunities in the developed World. It is therefore ironical and paradoxical that the lopsided nature of the present international economy is strikingly brought home by the fact that the underdeveloped countries have in turn to recruit foreign experts at fantastic cost.

Besides, he is of the view that it is typical of underdeveloped economies that they do not concentrate on those sectors of the economy which in turn will generate growth and raise production to a new level altogether, and there are very few ties between one sector and another so that agriculture and industry could react beneficially on each other. In the same vein, it is to be maintained that whatever savings are made within the economy are mainly sent abroad or are frittered away in consumption rather than being redirected to productive purposes. Much of the national income which remains within the country gives to pay individuals who are directly involved in producing wealth but only in rendering auxiliary services civil servants, merchants, soldiers, etc. What aggravates the situation is that more people are employed in those jobs than are really necessary to give efficient service; and to crown it all, these people do not reinvest in agriculture or industry. They squander the wealth created by the peasants and workers by purchasing cars, whisky and perfumes (Ibid, 26).

\section{Recommendations}

1. Good leaders are not born, but made, hence, training is 


\section{Philosophy International Journal}

very essential for those aspiring to become leaders at all levels.

2. Government has to be made less attractive to those who see it as the surest cum fastest means to easy wealth.

3. Nigeria must look inwards for solution to the myriad of problems confronting her.

4. The economic and political structure must be redressed in such a way that the reward system is equitable and just.

5. We need carefully articulated Philosophy to remove the wrong ideas from our people that leadership is a privilege position to partake in the nation's cake.

6. The attitude of late Nelson Mandela, Thabo Mbeki, Abdou Diouf in stepping down before they are pushed or before they die is worth emulating.

7. There is need for us all to sit up, cogitate, ruminate, pontificate, reflect on our situation and experience; and thereby raise our consciousness, and get prepared and set to forge ahead inspite of odds and romance development.

8. There is need for total reconstruction of our society; in short, both re-examination, re-evaluation of values, choices, life options, and structural transformation.

9. If we must curb corruption in Nigeria, we must, first, begin to select leaders along the line of African spirituality. Africans should consult the gods, spirits and ancestors in their lands before they make a choice of leaders. As Awolalu [28] concludes while explaining the role of spirituality in Yoruba political system, Orunmila is believed to be specially gifted with knowledge and wisdom. He knew the secret of man's lot, and could direct him on how to rectify it because ... he was (said to be) present when man was created and his destiny sealed (Emphasis mine)... This suggests why in traditional Yoruba societies, the choice of any king would come from Orunmila who saw the future knew how such man would perform in office. There is no single African culture without at least, one such god. The Igbo people have Afa. In Egypt, they have Setiu. Leadership is more spiritual than physical, and a leader who is spiritually appointed is not likely to mislead and corrupt the people.

10. Ethics of governance must follow the contractual pattern of African spirituality. In the oath that the Nigerian public officials take before they are sworn in, for instance, and according to the 1999 Constitution, all issues raised are 'promises' upon promises, with no condition attached. This is a good example: 'I... solemnly swear/affirm that I will be faithful and bear true allegiance to the Federal Republic of Nigeria ... that I will not allow my personal interest to influence my official conduct or official decision..." And this is ended with the cliché 'so help me God.' A critical analysis of this oath reveals that it is empty and non-contractual. It is quite spurious, superfluous, ambiguous and porous. There is no part of the oath that says something like if I derail from these promises, may so so so, do so and so to me. Rather, what ends it is 'so help me God.' Any criminal can bend the rule and destroy the people only to give the excuse that God did not help him. To avert this type of confusion, the toughest god in each community should be involved in oath-taking by government officials. The Igbo people should use Amadioha; the Yoruba can use Sango or Sopona, while the Ondo can use Ayelala. No one who knows these gods will break a contract with them.

11. In addition to the above, it is strongly recommended that while political office holders take oath, the followers too should take in the same token, that they will not mount unnecessary pressure on political office holders such that will tempt them into corruption. It has been proved that people often expect material gains, rather than official commitments, from government officials.

Finally, Oladipo [29] maintains that: In this process, we undermine our own vital interests, thereby further enmeshing ourselves in the web of underdevelopment. To dismantle this web, it is essential that we imbibe the lessons of the following Yoruba proverbs:

- Atelewo eni ki i tan eni je. (A person is never deceived by his palms)

- Owo are eni la a fin tun iwa ara eni se. (Self-help is the best form of assistance; or a person can modify her character only through personal effort)

- Ile ni a ti n ko eso r'ode. (Charity begins at home)

- Bi odede ko dun, bi i igbe ni ilu ri. (If the home is not at peace, the town would appear like a jungle)

Applied to the problem of African underdevelopment, the implications of these proverbs are essentially three. The first one is that to make African development a reality, Africans world have to be realists in Cabral sense. That is, we have to make the reality of our time and place the basis of the choice of our development options. The second one is that Africans would have to be the architects of their own development. This is how Professor Adebayo Adedeji, erstwhile Executive Secretary of the Economic Commission for Africa (ECA), aptly express it; Europeans developed Europe, Americans transformed America and Japanese developed Japan, and so only Africans themselves can develop Africa. We can only be assisted by our foreign development partners. (1990: ix).

The third implication is that African development would be impossible unless we secure the conditions for political stability, particularly coherent, legitimate and effective states. This shows clearly the futility of focusing narrowly on the economy in pursuing the goal of social reconstruction in Africa. The import of all this is that self-development is the best form of development and that no significant social transformation can occur on the continent unless we break 


\section{Philosophy International Journal}

the yoke of the culture of dependency [30].

Securing the conditions of African development in the contemporary world, which have been highlighted above, requires not only a leadership that finds its hope and commitment in the people as subjects and agents of development. It also requires that the sovereign will of the people to organize their economic, political and social affairs is respected. Finally, it requires a new panAfricanism. The focus of this pan-Africanism would be on the collective mobilization of resources, mental and material, for overcoming the inhibiting conditions of African existence in the contemporary world, particularly the condition of educational, scientific and technological underdevelopment. This is the most effective way of regaining the initiative, still lost, for autonomous socio-economic development.

\section{Conclusion}

In this paper, we have discussed leadership, qualities of a good leader, development, its dimensions and features. The synergy or link between leadership and development is equally discussed. Also, some recommendations are made. The truth of the matter is that heaven helps those who help themselves and in the Holy Quran, Allah says: "Verily, never will Allah change the condition of a people until they change it themselves..."

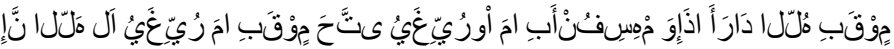

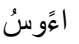

Q 13 verse 11 . The paper therefore concludes that the development of Nigeria is dependent on good, effective, vibrant, resounding, visionary and focused leadership. Also, the extent to which the ideas being pointed out are vigorously pursued and given attendant practical implementation will determine the place of Nigeria in the league of Nations of the World in the 21st century.

\section{References}

1. Tella A (2014) The Affluent Society: Can Africa Make It? Inaugural Lecture, Olabisi Onabanjo University, AgoIwoye.

2. George $O$ (2012) "Diabetic Economy: A paradox and a Dilemma". Inaugural Lecture, Olabisi Onabanjo University, Ago-Iwoye.

3. Achebe C (2012) There Was A Country: A Personal History of Biafra. Penguin Group, USA.

4. Achebe C (1983) The Trouble with Nigeria. Enugu: Fourth Dimension Publication.

5. Ayittey G (1992) "Africa Betrayed", New York: First paperback.

6. Falaiye M (2012) "A Philosopher Interrogates African Polis: How Can We Get It?" University of Lagos Inaugural Lecture Series.

7. Ihonvbere J (2011) Reinventing Africa for the Challenges of the Twenty-First Century. CBAAC Occasional Monographs, Lagos, Malthouse Press Limited.

8. Uduigwomen AF, Ogbinaka K (1999) "Philosophy and Education", Lagos: Obaroh \& Ogbinaka Publishers Ltd.

9. Timamy K (2007) The Political Economy of Technological Underdevelopment in Africa, Lagos: CBAAC.

10. Ojukwu EO (1996) "Because I am involved". Lagos: Spectrum Books Ltd.

11. Momoh CS (1998) "The Funeral of Democracy in Nigeria”. Auchi: African Philosophy projects' publication.

12. Hagher I (2002) "Leading Africa out of Chaos". Ibadan: Spectrum Books Ltd.

13. Wiredu K (1980) Conceptual Decolonization in African Philosophy: 4 Essays. Ibadan: Hope publications.

14. Mcgurk H (1975) Growing and Changing, London: Methuen \& Co.

15. Haris D (1957) The Concept of Development, Minnesota: University of Minnesota Press.

16. Unah J (1996) Heidegger's Existentialism: An Essay on Applied Ontology, Lagos: Panaf.

17. Ake C (2001) Democracy and Development in Africa. Ibadan: Spectrum Books.

18. Balogun K (1988) The Place of Religion in the Development of Nigeria, Ilorin: Amora Press Ltd.

19. Udoidem I (1992) Values and National Development, Lagos: African Heritage.

20. Ogundowole K (2002) "Self-reliance and National Development". In: Ogundowole K (Ed.) Philosophy and Logic. A Student Companion, Lagos: Obaroh \& Ogbinaka Publishers Ltd.

21. Miller H (1947) An Historical Introduction to Modern Philosophy. McGraw-Hill Inc., New York.

22. Pearson LB (1900) The Crisis of Development, London: Paul Mall Press Ltd.

23. Dukor M (2003) Philosophy and Politics. Discourse on 
Values, Politics and Power in Africa, Lagos: Obaroh \& Ogbinaka.

24. Fadahunsi A (1998) Philosophy: An Anthology, Lagos: Ark Publishers.

25. Awolowo O (1968) The People's Republic. Ibadan: Oxford University Press.

26. Onimode, Synge R (Eds.) (1995), "Issues in African Development", Ibadan: Heinemann Educational Books.
27. Rodney W (1972) How Europe Underdeveloped Africa, London: Bogle L'ouverture Publications.

28. Awolalu (1979) Yoruba Beliefs and Sacrificial Rites. Longman, UK.

29. Oladipo 0 (2008) "The Need for a Social Philosophy in Africa” being convocation lecture delivered at Ambrose Alli University, Ekpoma, Nigeria.

30. Stewart F (1972) Technology and Underdevelopment, London: Macmillan. 